\title{
FAKTOR-FAKTOR YANG MEMPENGARUHI PROFITABILITAS BANK UMUM SYARIAH TAHUN 20I 2-20I7
}

\author{
Eni Suharti', Ulfah Salpiah² \\ Universitas Muhammadiyah Tangerang \\ suharti_eni@yahoo.co.id
}

Keyword
Profitability, CAR, BOPO and NPF

\begin{abstract}
This study aims to determine the effect of Capital Adequacy Ratio (CAR), Operational Income Operating Costs (BOPO) and Non Performing Financing (NPF) on profitability (ROA) in Islamic Commercial Banks. This study uses a quantitative approach. The population in this study were 13 Islamic Commercial Banks registered in the Financial Services Authority (OJK). The sampling technique used was random sampling, which is a Sharia Commercial Bank that is categorized as Good Financial Performance and Islamic Bank Category in 2017 and obtained a sample of 5 Islamic Commercial Banks. The analysis technique used is multiple regression and hypothesis testing using tstatistics to test partial regression coefficients and f-statistics to test the significance of the effects together. In addition, a classic assumption test is also conducted which includes normality test, autocorrelation test, heteroscedasticity test and multicollinearity test. The results of this study indicate that partially CAR does not affect ROA in Sharia Commercial Banks, BOPO partially has a negative and significant effect on ROA in Islamic Commercial Banks, NPF partially has a negative and significant effect on ROA in Islamic Commercial Banks. Simultaneously CAR, BOPO and NPF have a significant effect on the depedent variable (ROA) of Islamic Commercial Banks.
\end{abstract}

\section{PENDAHULUAN}

\section{Latar Belakang Masalah}

Indonesia salah satu Negara dengan penduduk muslim terbesar di dunia yang mayoritas penduduknya beragama Islam menjadikan Indonesia sebagai pasar yang potensial dalam pengembangan keuangan syariah. Bahkan kini bank-bank konvensional pun mendirikan institusi syariah atau unit syariah agar tetap mampu bersaing dalam dunia perbankan dan memiliki banyak nasabah yang tertarik dengan kegiatan syariah.

Mengingat begitu pentingnya fungsi dan peranan perbankan syariah di Indonesia, maka pihak bank syariah perlu meningkatkan kinerjanya agar tercipta perbankan dengan prinsip syariah yang sehat dan efisien. Profitabilitas merupakan indikator yang paling tepat untuk mengukur kinerja suatu bank.
Profitabilitas merupakan kemampuan suatu perusahaan untuk mendapatkan laba atau keuntungan dalam suatu periode tertentu. Profitabilitas suatu perusahaan akan mempengaruhi kebijakan para investor atas investasi yang dilakukan. Kemampuan perusahaan untuk menghasilkan laba akan dapat menarik para investor untuk menanamkan dananya untuk memperluas usahanya, sebaliknya tingkat profitabilitas yang rendah akan menyebabkan para investor menarik dananya dan memindahkannya ke Bank lain.

Semakin tinggi profitabilitas bank syariah maka semakin baik pula kinerja bank tersebut. Kinerja bank syariah dapat dinilai melalui berbagai macam variabel yang diambil dari laporan keuangan bank syariah. Laporan keuangan tersebut menghasilkan sejumlah rasio keuangan yang dapat membantu para pemakai 
laporan keuangan dalam menilai kinerja bank syariah.

Penilaian terhadap kinerja suatu bank dapat dilakukan dengan melakukan analisis terhadap laporan keuangannya.Rasio profitabilitas merupakan rasio untuk menilai kemampuan perusahaan dalam kencari keuntungan.Penggunaan rasio profitabilitas dapat dilakukan dengan menggunakan perbandingan antar berbagai komponen yang ada dilaporan keuangan.Rasio profitabilitas yang penting bagi bank adalah Return On Asset (ROA). ROA penting bagi bank karena ROA digunakan untuk mengukur efektivitas perusahaan di dalam menghasilkan keuntungan dengan memanfaatkan aktiva yang dimilikinya.

Capital Adequacy Ratio (CAR) merupakan rasio permodalan yang menunjukkan kemampuan bank dalam menyediakan dana untuk keperluan pengembangan usaha dan menampung risiko kerugian dana yang diakibatkan oleh kegiatan operasi bank. CAR menunjukkan sejauh mana penurunan aset bank masih dapat ditutup oleh Equity bank yang tersedia, semakin tinggi CAR semakin baik kondisi sebuah bank (Tarmidzi Achmad, 2003). Dengan demikian tingginya nilai CAR dapat menambah kepercayaan masyarakat terhadap bank, karena jaminan dana masyarakat semakin tinggi. Dengan kondisi demikian akan meningkatkan perolehan laba dari bank.

Biaya Operasional/Pendapatan Operasional (BOPO) digunakan untuk mengukur tingkat efisiensi dan kemampuan bank dalam melakukan kegiatan operasinya. Mengingat kegiatan utama bank pada prinsipnya adalah bertindak sebagai perantara, yaitu menghimpun dan menyalurkan dana masyarakat, maka biaya dan pendapatan operasional bank didominasi oleh biaya bunga dan hasil bunga. Setiap peningkatan biaya operasional akan berakibat pada berkurangnya laba sebelum pajak yang pada akhirnya akan menurunkan laba atau profitabilitas (ROA) bank yang bersangkutan.

Non Performing Financing (NPF) dijadikan variabel yang mempengaruhi profitabilitas karena mencerminkan risiko pembiayaan. Semakin tinggi rasio ini, menunjukkan kualitas pembiayaan bank syariah semakin buruk. Tingkat kesehatan pembiayaan (NPF) ikut mempengaruhi pencapaian laba bank. Pengelolaan pembiayaan sangat diperlukan oleh bank, mengingat fungsi pembiayaan sebagai penyumbang pendapatan terbesar bagi bank syariah.

Rasio-rasio keuangan yang mempengaruhi ROA adalah CAR, Biaya Operasional/Pendapatan Operasional (BOPO), dan Non Performing Financing (NPF). Sebagaimana hasil penelitian yang dilakukan Abdillah (2015) mengemukakan, bahwa Capital Adequacy Ratio (CAR)dan BOPO memiliki pengaruh signifikan positif terhadap ROA.

Syamsurizal(2016) mengemukakan, bahwa CAR dan NPF berpengaruh positif dan signifikan terhadap ROA, sedangkan BOPO berpengaruh negatif dan signifikan terhadap ROA.

Aditya (20/3) dan Ananda (20/3) mengemukakan hasil penelitianya, bahwa Biaya Operasional/Pendapatan Operasional (BOPO) berpengaruh signifikan negatif terhadap ROApada Bank Syariah. Sedangkan Syaugi(2015) mengemukakan CAR tidak berpengaruh signifikan terhadap ROA.

Dari research gappada penelitian yang telah dilakukan sebelumnya, terjadi ketidak konsistenan hasil penelitian. Selain itu didukung dengan adanya fenomena business gap mengenai rasio-rasio yang diteliti dari keuangan Bank Umum Syariah di Indonesia, berikut dapat dilihat pada tabel I yang menyajikan perkembangan rata-rata rasio keuangan Bank Umum Syariah di Indonesia selama periode 2012-2017.

Tabel I. Rata-rata dari ROA, CAR, BOPO, dan NPF Bank Umum Syariah Tahun 20 I 2-20I7

\begin{tabular}{lllllll}
\hline RASIO & 2012 & 2013 & 2014 & 2015 & 2016 & 2017 \\
\hline ROA & $2,14 \%$ & $2,00 \%$ & $0,41 \%$ & $0.49 \%$ & $0.63 \%$ & $0.63 \%$ \\
\hline CAR & $14,13 \%$ & $14.42 \%$ & $15,74 \%$ & $15,02 \%$ & $16,63 \%$ & $17,91 \%$ \\
\hline BOPO & $74,97 \%$ & $78,21 \%$ & $96,97 \%$ & $97,01 \%$ & $96,22 \%$ & $94,91 \%$ \\
\hline NPF & $2,22 \%$ & $2,62 \%$ & $4,95 \%$ & $4,84 \%$ & $4,42 \%$ & $4,77 \%$
\end{tabular}

Sumber: Statistik Perbankan Syariah (OJK)

Tabel I di atas rata-rata rasio variabel penelitian pada Bank Umum Syariah Tahun 2012-2017, terdapat beberapa informasi mengenai adanyafenomena business gap, antara lain :
I. Dari tahun 2012-2017 ROA mengalami penurunan yang menggambarkan bahwa Bank Umum Syariah tidak mampu memanfaatkan aset untuk meningkatkan laba Bank Umum Syariah. 
2. Dari tahun 20I2-20I7 CAR mengalami kenaikan yang menggambarkan Bank Umum Syariah semakin kuat kemampuannya untuk menanggung resiko dari setiap kredit. Sehingga dapat dikatakan bahwa kondisi permodalan pada Bank Umum Syariah dalam kondisi sehat.

3. Dari tahun 2012-2017 BOPO mengalami fluktuatif yang menggambarkan bahwa Bank Umum Syariah masih belum mampu dalam mengelola atau mengendalikan biaya operasionalnya dan memaksimalkan pendapatan.

4. Dari tahun 2012-20I7 NPF mengalami fluktuatif yang menggambarkan bahwa Bank Umum Syarah masih belum mampu mengatasi pembiayaan yang tidak lancar.

Dengan adanya perbedaan dalam research gap dari penelitian terdahulu sehingga perlu dilakukan penelitian lanjutan yang meneliti permasalahan faktor-faktor yang mempengaruhi Return On Asset (ROA). Faktor-faktor tersebut terdiri dari variabel Capital Adequacy Ratio (CAR), Biaya Operasional terhadap Pendapatan Operasional (BOPO)danNon Performing Financing (NPF).

\section{Rumusan Masalah}

Penelitian ini mengajukan empat pertanyaan penelitian (research question) yangmenjadi permasalahan, antara lain :, yaitu:

I. Bagaimana Capital Adequacy Ratio (CAR) berpengaruh terhadap profitabilitas (ROA) pada Bank Umum Syariah?

2. bagaimana Biaya Operasional Pendapatan Operasional (BOPO) berpengaruh terhadap profitabilitas (ROA) pada Bank Umum Syariah?

3. Bagaimana Non Performing Financing (NPF) berpengaruh terhadap profitabilitas (ROA) pada Bank Umum Syariah?

4. Bagaimana CAR, BOPO dan NPF, berpengaruh secara bersama-sama terhadap profitabilitas (ROA) pada Bank Umum Syariah?

\section{Pengembangan Hipotesis Penelitian}

CAR atau dikenal juga dengan rasio kecukupan modal merupakan kemampuan bank untuk menutup risiko kerugian dari aktivitas yang dilakukannya dan kemampuan bank dalam mendanai kegiatan operasionalnya, Mokoagow dan Fuady (2015). Menurut peraturan Bank Indonesia Nomor 10/I5/PBI/2008 pasal 2 ayat I tercantum bank wajib menyediakan modal minimum sebesar $8 \%$ dari asset tertimba menurut resiko (ATMR).
Adapun besarnya nilai CAR dirumuskan yaitu:

$$
\mathrm{CAR}=\frac{M \quad S}{A^{\prime}} X 100 \%
$$

Dengan asumsi bahwa CAR adalahketersediaan modal sehingga dengan kondisisuatu bank yang memiliki rasio CAR yang besarakan membuat bank tersebut dapat lebih fleksibeldalam menjalankan operasionalnya sehinggapenetrasi ke pasar dapat dilakukan (Catur Wahyu Endra Yogianta, 2013). Menurut penelitian yang dilakukan oleh Syamsurizal(2016) bahwa CAR berpengaruh positif dan signifikan terhadap ROA.

Dari uraian tersebut hipotesis pertama dalam penelitian adalah :

$\mathrm{HI}$ : CAR berpengaruh signifikan positif terhadap profitabilitas (ROA)

BOPO menurut kamus keuangan adalah kelompok rasio yang mengukurefisiensi dan efektivitas operasional suatu perusahaan dengan jalurmembandingkan satu terhadap lainnya. menurut Rivai dkk. (2007) Rasio BOPO adalah perbandinganantara biaya operasional dengan pendapatan operasional dalam mengukur tingkatefisiensi dan kemampuan bank dalam melakukan kegiatan operasinya. Dalam halini perlu diketahui bahwa usaha utama bank adalah menghimpun dana darimasyarakat dan selanjutnya menyalurkan kembali kepada masyarakat dalambentuk kredit, sehingga beban bunga dan hasil bunga merupakan porsi terbesar bagi bank. Rasio ini dirumuskan dengan:

$$
\text { ВОРО }=\frac{B \quad O}{P} X 100 \%
$$

Semakin tinggi angka pada rasio menunjukkan semakin tidak efisiensinya suatu bank dalam menjalankan operasionalnya. Ketidak efisienan ini menimbulkan alokasi biaya yang lebih tinggi sehingga dapat menurunkan pendapatan bank.Hal ini didukung oleh penelitian Aditya (20/3), Ananda (20/3), Syamsurizal (2016) dan Petricia (2017), BOPO berpengaruh signifikan negatif terhadap ROA. adalah :

Dari uraian tersebut hipotesis kedua

$\mathrm{H} 2$ : BOPO berpengaruh negatif terhadap profitabilitas (ROA)

Non Performing Financing(NPF) merupakan pembiayaan bermasalah yangdilakukan oleh debitur pada suatu jenis pembiayaan tertentu akibat adanyakesengajaan atau faktor lain diluar 
kemampuan kendali debitur. Risiko kreditmerupakan resiko yang paling serius bagi setiap lembaga keuangan. Risiko inimuncul dari ketidakmampuan debitur untuk menunaikan kewajibannya yang telahjatuh tempo berdasarkan kesepakatan. Risiko kredit yang terus berlanjut, tidakhanya akan menimbulkan kesulitan likuiditas, tetapi juga bisa menurunkankualitas asset yang dimiliki oleh pihak bank.(M.Umer Chapra,2008:75).Menurut laporan tahunan Perbankan Nasionalsesuai surat edaran BI No. 9/24/DPbs 30 Oktober 2007 tentang sistem penilaiankesehatan bank berdasarkan prinsip syari'ah yang dirumuskan sebagai berikut:

$$
\text { ВОРО }=\frac{P_{\ell} \quad(K, L, D)}{T \quad P_{\ell}} X 100 \%
$$

Kriteria penilaian peringkat Non Performing Financing menurutSurat Edaran BI No. 9/24/DPbs tanggal 30 Oktober 2007 adalah sebagai berikut :

Tabel 2. Kriteria Penilaian Peringkat Non Performing Financing

\begin{tabular}{|c|l|l|}
\hline Peringkat & \multicolumn{1}{|c|}{ Nilai NPF } & \multicolumn{1}{|c|}{ Predikat } \\
\hline I & NPF $<2 \%$ & Sangat Baik \\
\hline 2 & $2 \% \leq$ NPF $<5 \%$ Baik & Baik \\
\hline 3 & $5 \% \leq$ NPF $<8 \%$ & Cukup Baik \\
\hline 4 & $8 \% \leq$ NPF $<12 \%$ & Kurang Baik \\
\hline 5 & NPF $\geq 12 \%$ & Tidak Baik \\
\hline
\end{tabular}

Sumber: SE BI No. 9/24/DPbs tanggal 30 Oktober 2007

NPF atau risiko pembiayaan merupakan risiko akibat dari ketidak mampuan nasabah dalam mengembalikan pinjaman beserta imbalannya dalam jangka waktu tertentu. NPF merupakan perbandingan antara jumlah pembiayaan bermasalah dengan total seluruh pembiayaan. Tingginya pembiayaan bermasalah mencerminkan banyaknya nasabah yang tidak bisa mengembalikan pinjaman atau pembiayaan yang diajukan kepada perbankan, hal ini menunjukkan kinerja perbankan yang buruk. Pembiayaan bermasalah ini mempengaruhi perolehan laba bank syariah, yang pada akhirnya akan menurunkan tingkat profitabilitas (ROA).

Ananda (2013) dalam penelitiannya menyatakan NPF berpengaruh negatif dan signifikan terhadap ROA.

Dari uraian tersebut hipotesis ketiga adalah :

H3 : NPF berpengaruh negatif terhadap profitabilitas (ROA)
Dalam hal ini mengukur hubungan antara CAR, NPF, dan BOPO dengan profitabilitas (ROA) pada bank (secara simultan). Oleh karena itu, dapat hipotesis sebagai berikut:

H4 : CAR, NPF dan BOPO berpengaruh signifikan secara bersama-sama terhadap profitabilitas (ROA)

\section{METODE PENELITIAN}

\section{Desain Penelitian}

Jenis penelitian berdasarkan tingkat eksplanasinya (tingkat kejelasan) adalah penelitian asosiatif. Menurut Sugiyono (2003:14) penelitian asosiatif merupakan penelitian yang bertujuan untuk mengetahui pengaruh ataupun juga hubungan antara dua variabel atau lebih.

\section{Populasi dan Sampel}

Populasi dalam penelitian ini adalah Bank Umum Syariah yang terdaftar di Bank Indonesia. Sample yang digunakan adalah bank umum syariah yang masuk kategori Good Financial Performance dan Category Islamic Bank tahun 2017 yang bersumber dari www.wartaekonomi.co.id.

Dari kategori Good Financial Performance dan Category Islamic Bank tahun 2017, didapatkan 5 bank umum syariah yaitu:

Tabel 3. Sampel Bank Umum Syariah

\begin{tabular}{|c|l|}
\hline No & \multicolumn{1}{|c|}{ Bank Umum Syariah } \\
\hline I & Bank BCA Syariah \\
\hline 2 & Bank BNI syariah \\
\hline 3 & Bank BRI Syariah \\
\hline 4 & Bank Syariah Bukopin \\
\hline 5 & Bank Syariah Mandiri \\
\hline
\end{tabular}

Sumber: data diolah oleh, penelitian 2018

Sampel adalah perwakilan dari populasi atau sebagian dari populasi yang akan di teliti yang dapat mewakili seluruh populasi tersebut. Penentuan sampel dalam penelitian ini yaitu penentuan sampel dengan teknik sampling probability sampling, yaitu sensus. Metode ini menetapkan bahwa populasi merupakan sample penelitian.

\section{Definisi Operasional}

\section{Variabel Dependen}

Return On Asset (ROA) adalah rasio yang menggambarkan kemampuan bank dalam mengelola dana yang diinvestasikan dalam keseluruhan aktiva yang menghasilkan keuntungan. ROA adalah gambaran produktivitas bank dalam mengelola dana sehingga menghasilkan keuntungan, Muhamad (20I4). Semakin besar Return On Asset (ROA) 
menunjukkan kinerja perusahaan semakin baik, karena return semakin besar.

Adapun ROA bisa dirumuskan sebagai berikut :

$$
\mathrm{ROA}=\frac{L \quad \text { St } \quad P}{T \quad A} X 100 \%
$$

Klasifikasi tingkat ROA menurut Bank Indonesia secara rinci adalah sebagai berikut:

\section{Tabel 4. Klasifikasi ROA Menurut BI}

\begin{tabular}{ll}
\hline Tingkat ROA & Predikat \\
\hline Di atas I,22\% & Sehat \\
\hline $0,99 \%-1,22 \%$ & Cukup Sehat \\
\hline $0,77 \%-0,99 \%$ & Kurang Sehat \\
\hline Di bawah $0,77 \%$ & Tidak Sehat
\end{tabular}

Sumber: www.bi.go.id

\section{Variabel Indepeden}

Variabel independen yang digunakan yaitu

Capital Adequacy Ratio $\left(\mathrm{X}_{1}\right)$, Biaya Operasional/Pendapatan Operasional $\left(\mathrm{X}_{2}\right)$, dan Non Performing Financing $\left(\mathrm{X}_{3}\right)$.Capital Adequacy Ratio (CAR) atau dikenal juga dengan rasio kecukupan modal merupakan kemampuan bank untuk menutup risiko kerugian dari aktivitas yang dilakukannya dan kemampuan bank dalam mendanai kegiatan operasionalnya, Mokoagow dan Fuady (2015).Adapun besarnya nilai CAR dirumuskan sebagai berikut :

$$
\mathrm{CAR}=\frac{M S}{A^{\prime}} X 100 \%
$$

Klasifikasi tingkat CAR menurut Bank Indonesia secara rinci adalah sebagai berikut:

Tabel 5. Klasifikasi CAR Menurut BI

\begin{tabular}{ll}
\hline Tingkat CAR & Predikat \\
\hline $8 \%$ ke atas & Sehat \\
\hline $6,4 \%-7,9 \%$ & Kurang Sehat \\
\hline Di bawah $6,4 \%$ & Tidak Sehat \\
\hline
\end{tabular}

Biaya Operasional/Pendapatan Operasional (BOPO), digunakan untuk mengukur perbandingan biaya operasi atau biaya intermediasi terhadap pendapatan operasi yang diperoleh oleh bank. Semakin kecil BOPO berarti semakin efisien biaya operasional yang dikeluarkan bank yang bersangkutan sehingga kemungkinan suatu bank dalam kondisi bermasalah dan semakin kecil rasio ini maka kinerja bank semakin baik. Dengan demikian, efisiensi operasi suatu bank yang diproksikan dengan rasio $\mathrm{BOPO}$ akan mempengaruhi kinerja bank tersebut.

BOPO dapat dihitung dengan rumus sebagai berikut.

$$
\mathrm{BOPO}=\frac{B \quad O}{P} X 100 \%
$$

Klasifikasi tingkat BOPO menurut Bank Indonesia secara rinci adalah sebagai berikut:

\section{Tabel 6. Klasifikasi BOPO Menurut BI}

\begin{tabular}{ll}
\hline Tingkat BOPO & Predikat \\
\hline Di bawah $93,52 \%$ & Sehat \\
\hline $93,52 \%-94,72 \%$ & Cukup Sehat \\
\hline $94,72 \%-95,92 \%$ & Kurang Sehat \\
\hline Di atas $95,92 \%$ & Tidak Sehat \\
\hline
\end{tabular}

Sumber: www.bi.go.id

Non Performing Financing (NPF) atau dikenal juga dengan risiko pembiayaan adalah risiko akibat ketidak mampuan nasabah dalam mengembalikan pinjaman yang telah diberikan oleh bank beserta imbalannya dalam jangka waktu tertentu. Menurut Zulifiah dan Susilowibowo (2014) nilai NPF dapat dirumuskan sebagai berikut:

$$
\mathrm{NPF}=\frac{J u \quad h B \quad B}{P P_{t}} \times 100 \%
$$

Klasifikasi tingkat NPF menurut Bank Indonesia secara rinci adalah sebagai berikut:

Tabel 7. Klasifikasi NPF Menurut BI

\begin{tabular}{ccc}
\hline Peringkat & Nilai NPF & Predikat \\
\hline 1 & NPF $<2 \%$ & Sangat Baik \\
\hline 2 & $2 \% \leq \mathrm{NPF}<5 \%$ & Baik \\
\hline 3 & $5 \% \leq \mathrm{NPF}<8 \%$ & Cukup Baik \\
\hline 4 & $8 \% \leq \mathrm{NPF}<12 \%$ & Kurang Baik \\
\hline 5 & $\mathrm{NPF} \geq 12 \%$ & Tidak Baik \\
\hline
\end{tabular}


Tabel 8. Operasioalisasi Variabel Penelitian

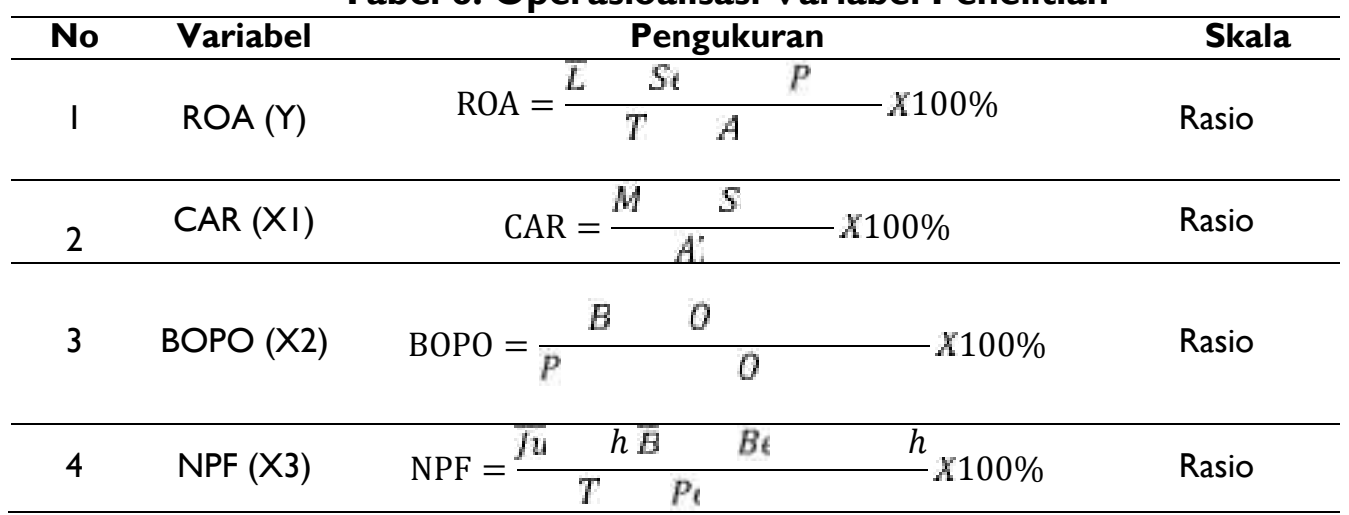

Sumber: Kasmir (20I7), Noerfikri (20I5)

\section{Teknik Pengumpulan Data}

Data yang digunakan peneliti adalah data sekunder, data sekunder merupakan data yang diperoleh dalam bentuk yang sudah ada, sudah dikumpulkan dan diolah oleh pihak lain. Data sekunder yang digunakn pada penelitian ini adalah laporan keuangan tahunan bank umum syariah yang sudah dipublikasikan oleh masingmasing bank.

\section{Teknik Analisis Data}

Teknik analisis yang digunakan adalah regresi berganda dengan persamaan kuadrat terkecil dan uji hipotesis menggunakan t-statistik untuk menguji koefisien regresi parsial serta $f$ statistik untuk menguji keberartian pengaruh secara bersama-sama dengan level of significance $5 \%$.Selain itu juga dilakukan uji asumsi klasik yang meliputi uji normalitas, uji autokorelasi, uji heteroskedastisitas dan uji multikolinieritas untuk memastikan bahwa prasyarat regresi terpenuhi.

\section{HASIL PENELITIAN DAN PEMBAHASAN}

\section{Hasil Penelitian}

\section{Uji Asumsi Klasik}

Uji asumsi klasik digunakan, apakah model regresi yang digunakan dalam penelitian ini layak diuji atau tidak. Pengujian asumsi klasik untuk memastikan bahwa sampel yang diteliti terbebas dari gangguan Normalitas, Autokorelasi, Heteroskedastisitas, dan Multikolonieritas. Uji asumsi klasik pada penelitian ini adalah sebagai berikut :

\section{a. Uji Normalitas}

Pengujian normalitas dilakukan dengan $U_{j i}$ Kolmogrov-Smirnov yang dilakukan terhadap data residual model regresi. Adapun pengujian total sampel data disajikan pada berikut ini:

Tabel 9. Hasil Uji Normalitas

One-Sample Kolmogorov-Smirnov Test

\begin{tabular}{llr}
\hline & & Unstandardized Residual \\
\hline $\mathrm{N}$ & Mean & 30 \\
Normal Parametersa,b & Std. Deviation &, 0000000 \\
& Absolute &, 17241239 \\
Most Extreme Differences & Positive &, 152 \\
& Negative &, 152 \\
Kolmogorov-Smirnov Z & &,- 121 \\
Asymp. Sig. (2-tailed) & &, 830 \\
\hline
\end{tabular}

a. Test distribution is Normal.

b. Calculated from data.

Sumber: Data diolah SPSS v2 I

Dari tabel 9 menunjukkan nilai Kolmogorov-Smirnov $Z$ sebesar 0,830 dan Asymp. Sig. (2-tailed)sebesar 0,496 dengan demikian nilai 
probabilitas lebih besar dari 0,05 atau 0,496 > 0,05 . Hal itu menunjukkan bahwa secara keseluruhan variabel berdistribusi normal.

b. Uji Autokorelasi
Dalam pengujian ini digunakan Uji DurbinWatson (DW). Hasil pengujian dapat dilihat dari tabel berikut ini:

Tabel I0. Hasil Uji Autokorelasi

Model Summary

\begin{tabular}{lrrrrr}
\hline Model & $\mathrm{R}$ & R Square & $\begin{array}{r}\text { Adjusted R } \\
\text { Square }\end{array}$ & $\begin{array}{r}\text { Std. Error of the } \\
\text { Estimate }\end{array}$ & $\begin{array}{r}\text { Durbin- } \\
\text { Watson }\end{array}$ \\
\hline $\mathrm{I}$ &, $925^{\mathrm{a}}$ &, 856 &, 840 &, 18209 & $\mathrm{I,260}$ \\
\hline
\end{tabular}

a. Predictors: (Constant), NPF, BOPO, CAR

b. Dependent Variable: ROA

Sumber: Data diolah SPSS v2 I

Dari tabel diatas nilai DW sebesar I,260 nilai ini akan kita bandingkan dengan nilai tabel dengan menggunakan nilai signifikan $5 \%$ jumlah sample penelitian ini adalah $30 \quad(T=30)$ dan jumlah variabel $3(\mathrm{~K}=3)$, maka didapat nilai $\mathrm{D}_{\mathrm{L}}=$ 12138 dan nilai $d_{u}=16498$, maka tabel diatas nilai DW menghasilkan $\mathrm{dl}<\mathrm{DW}<$ du atau $12138<1,260<16498$, maka dapat dinyatakan uji autokorelasi tidak meyakinkan atau tidak dapat disimpulkan. Dengan begitu harus dilakukan Uji Runs Test.

Tabel I I. Hasil Uji Runs Test

\section{a. Median}

Sumber : Data diolah SPSS v2 I

Runs Test

\begin{tabular}{|l|l|}
\hline & $\begin{array}{c}\text { Unstandardized } \\
\text { Residual }\end{array}$ \\
\hline Test Value &,- 04735 \\
Cases < Test Value & 15 \\
Cases >= Test Value & 15 \\
Total Cases & 30 \\
Number of Runs & $1 \mathrm{I}$ \\
Z & $-1,672$ \\
Asymp. Sig. (2-tailed) &, 094 \\
\hline
\end{tabular}

Berdasarkan tabel II dari hasil Uji Runs Test diketahui nilai Asymp. Sig (2-tailed) sebesar 0,094 lebih > dari 0,05, maka dapat disimpulkan bahwa tidak terdapat gejala atau masalah autokorelasi.

\section{c. Uji Heteroskedastisitas}

Pengujian ini dilakukan dengan menggunakan grafik Scatterplot. Hasil pengujian ini dapat dilihat dengan grafik sebagai berikut:

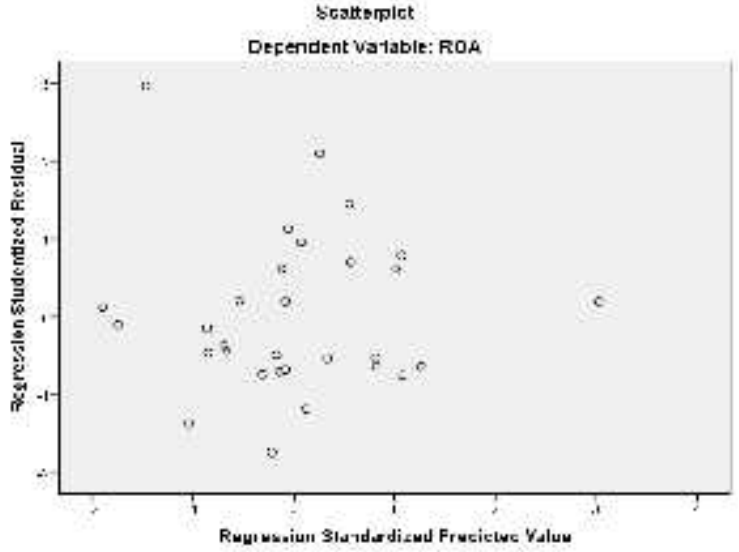

Gambar I. Grafik Scatterplot Sumber: Data diolah SPSS v2I

\section{d. Uji Multikolinearitas}

Uji ini dilakukan dengan Tolerance value dan Variance Inflation (VIF). Agar tidak terjadi Multikolinearitas, batas Tolerance value $>0$, I dan VIF $<10$. Hasil pengujian ini dapat dilihat pada tabel berikut:

Tabel I2. Hasil Uji Multikolinearitas Coefficients $^{\mathrm{a}}$

\begin{tabular}{cccc}
\hline & \multicolumn{2}{c}{ Model } & \multicolumn{2}{c}{ Collinearity Statistics } \\
\cline { 3 - 4 } & (Constant) & & VIF \\
\hline \multirow{2}{*}{ I } &, 457 & 2,189 \\
& CAR &, 605 & 1,654 \\
BOPO &, 363 & 2,758 \\
\hline
\end{tabular}

a. Dependent Variable: ROA

Sumber: Data diolah SPSS v2 I

Berdasarkan tabel diatas, dapat diketahui nilai Tolerance dan VIF untuk masing-masing variabel penelitian sebagai berikut:

I) Nilai Tolerance untuk variabel CAR sebesar $0,457>0,1$ dan nilai VIF sebesar $2,189<10$, sehingga variabel CAR dinyatakan tidak terjadi gejala multikolinearitas. 
2) Nilai Tolerance untuk variabel BOPO sebesar 0,605>0,I dan nilai VIF sebesar $1,654<10$, sehingga variabel BOPO dinyatakan tidak terjadi gejala multikolinearitas.

3) Nilai Tolerance untuk variabel NPF sebesar $0,363>0, I$ dan nilai VIF sebesar 2,758< 10, sehingga variabel NPF dinyatakan tidak terjadi gejala multikolinearitas.
Hasil analisis dan pengujian hipotesis dapat dijelaskan sebagai berikut:

\section{a. Uji t}

Tingkat kepercayaan yang digunakan dalam uji t ini adalah $95 \%$ atau taraf signifikan $5 \%$ $(a=0,05)$. Rumus untuk mencari t tabel $(a / 2 ; n-$ k-I) atau ( 0,05/2; 30-3-I). Angka yang didapat dari $t$ tabel sebesar 2.0555. Secara parsial pengaruhdari tiga variabel independen tersebut:

\section{Uji Hipotesis}

Tabel I3. Regresi Linier Secara Parsial Variabel CAR terhadap ROA

Coefficients $^{a}$

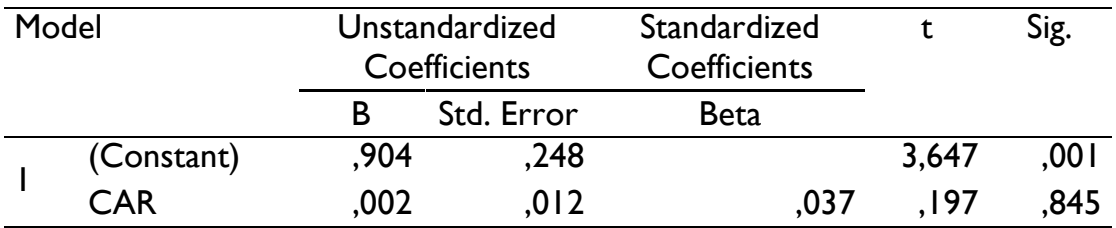

a. Dependent Variable: ROA

Sumber: Data diolah SPSS v2 I

Dari tabel I 3 maka diperoleh persamaan regresi linier sederhana sebagai berikut:

$R O A=0,904+0,002 C A R$. Angka yang didapat dari $\mathrm{t}$ tabel sebesar 2.0555, dan nilai $\mathrm{t}$ hitung berdasarkan hasil outputSPPS di atas adalah 0,197, sehingga dapat disimpulkan bahwa $t$ hitung sebesar 0,197< t tabel 2.0555, dan nilai signifikan $0,845>0,05$, maka secara parsial hipotesis Ho diterima dan $\mathrm{Ha}$ ditolak. Dengan demikian CAR berpengaruh secara signifikan terhadap ROA tidak terbukti.

Output SPSS untuk Regresi Linier secara Parsial Variabel BOPO terhadap ROA adalah sebagai berikut:

Tabel I4. Uji Parsial (uji t)Variabel BOPO terhadap ROA

\begin{tabular}{|c|c|c|c|c|c|c|}
\hline \multicolumn{7}{|c|}{ Coefficients ${ }^{a}$} \\
\hline & \multirow[t]{2}{*}{ Model } & \multicolumn{2}{|c|}{$\begin{array}{l}\text { Unstandardized } \\
\text { Coefficients }\end{array}$} & $\begin{array}{c}\text { Standardized } \\
\text { Coefficients }\end{array}$ & $\mathrm{T}$ & Sig. \\
\hline & & $B$ & Std. Error & Beta & & \\
\hline \multirow{2}{*}{ I } & (Constant) & 7,831 & ,56I & & 13,957 &, 000 \\
\hline & BOPO &,- 076 & ,006 &,- 918 & $-12,285$ &, 000 \\
\hline
\end{tabular}

a. DependentVariable: ROA

Sumber: Data diolah SPSS v2I

Dari tabel 14 maka diperoleh persamaan regresi linier sederhana sebagai berikut: ROA $=7,83 \mathrm{I}$ - 0,076BOPO.Berdasarkan hasil uji $\mathrm{T}$ pada tabel 13, diperoleh nilai $\mathrm{t}$ hitung sebesar 12,285, sedangkan $t$ tabel sebesar 2.05553 . sehingga dapat disimpulkan bahwa $t$ hitung sebesar $-12,285>t$ tabel 2.0555 , dengan nilai signifikan
$0,00<0,05$, maka secara parsial hipotesis Ho ditolak dan $\mathrm{Ha}$ diterima. Dengan demikian BOPO berpengaruh signifikan negatif terhadap ROA terbukti.

Output SPSS untuk Regresi Linier secara Parsial Variabel NPF terhadap ROA adalah sebagai berikut:

Tabel 15. Uji Parsial (uji t)NPF

\begin{tabular}{|c|c|c|c|c|c|c|}
\hline \multicolumn{7}{|c|}{ Coefficients $^{a}$} \\
\hline \multirow{2}{*}{\multicolumn{2}{|c|}{ Model }} & \multicolumn{2}{|c|}{$\begin{array}{l}\text { Unstandardized } \\
\text { Coefficients }\end{array}$} & \multirow{2}{*}{$\begin{array}{c}\text { Standardized } \\
\text { Coefficients }\end{array}$} & \multirow[t]{2}{*}{$T$} & \multirow[t]{2}{*}{ Sig. } \\
\hline & & $B$ & Std. Error & & & \\
\hline \multirow{2}{*}{ I } & (Constant) & 1,320 &, 136 & & 9,737 & ,000 \\
\hline & NPF &,- 119 & ,037 &,- 520 & $-3,222$ & ,003 \\
\hline
\end{tabular}

a. Dependent Variable: ROA

Sumber: Data diolah SPSS v2 I 
Dari tabel 15 maka diperoleh persamaan regresi linier sederhana sebagai berikut: ROA $=1,320-0,1$ I NPF Berdasarkan output SPSS pada tabel 19, diperoleh nilai $t$ hitung sebesar 3,222, $t$ tabel sebesar 2.05553. sehingga dapat

\section{b. Uji F}

Hasil dari pengujian degan regresi linier berganda dapat dilihat dibawah ini: disimpulkan bahwa nilai $t$ hitung sebesar $-3,222>$ $t$ tabel 2.05553, dengan nilai signifikan 0,003 < 0,05 , secara parsial hipotesis $\mathrm{Ho}$ ditolak dan $\mathrm{Ha}$ diterima. Dengan demikian NPF berpengaruh signifikan negatif terhadap ROA terbukti.

Tabel 16. Regresi Linier Berganda

\begin{tabular}{|c|c|c|c|c|}
\hline \multirow[t]{2}{*}{ Model } & & \multicolumn{2}{|c|}{ Unstandardized Coefficients } & \multirow{2}{*}{$\begin{array}{c}\text { Standardized Coefficients } \\
\text { Beta }\end{array}$} \\
\hline & & $B$ & Std. Error & \\
\hline \multirow{4}{*}{ I } & (Constant) & 7,473 &, 620 & \\
\hline & CAR &,- 001 &, 007 &,- 010 \\
\hline & BOPO &,$- 07 \mid$ & ,008 &,- 856 \\
\hline & NPF &,- 031 & ,028 &,- 136 \\
\hline
\end{tabular}

a. Dependent Variable: ROA

Sumber: Data diolah SPSS v21

Rumus persamaan Regresi Linear Berganda dalam penelitian ini adalah sebagai berikut:

ROA $=7,473-0,00 I C A R-0,07$ IBOPO 0,03 I NPF + e
Uji pengaruh simultan digunakan untuk mengetahui apakah variabel indepanden secara bersama-sama mempengaruhi variabel depeden. Dengan Tingkat kepercayaan yang digunakan dalam uji adalah $95 \%$ atau taraf signifikann $5 \%$ $(a=0,05)$.

Tabel I7. Uji Simultan (uji F)

\begin{tabular}{|c|c|c|c|c|c|c|}
\hline \multirow[b]{2}{*}{ Model } & & ANC & & & \multirow[b]{2}{*}{$\bar{F}$} & \multirow[b]{2}{*}{ Sig. } \\
\hline & & $\begin{array}{l}\text { Sum of } \\
\text { Squares }\end{array}$ & Df & $\begin{array}{l}\text { Mean } \\
\text { Square }\end{array}$ & & \\
\hline \multirow{3}{*}{ I } & Regression & 5,143 & 3 & 1,714 & 51,704 &, $000^{\mathrm{b}}$ \\
\hline & Residual & ,862 & 26 & ,033 & & \\
\hline & Total & 6,005 & 29 & & & \\
\hline
\end{tabular}

a. Dependent Variable: ROA

b. Predictors: (Constant), NPF, BOPO, CAR

Sumber: Data diolah SPSS v2I

Berdasarka hasil Uji Simultan (uji F)dapat dilihat bahwa $F_{\text {hitung }}$ sebesar 5I,704 dan apabila dilihat nilai $F$ tabel menggunakan signifikansi $5 \%$ (a $=0,05)$ dan degree of freedom $d f l(k-1)$ dan $d f 2$ $(n-k)$, yaitu $d f l=(4-I)=3$ dan $d f 2=(30-4)=$ 26 diperoleh nilai $F$ tabel sebesar 2.98 , sehingga dapat disimpulkan bahwa nilai $\mathrm{F}_{\text {hitung }}>\mathrm{F}$ tabel yaitu sebesar 5I,704 > 2,98 hal ini berarti Ho ditolak dan $\mathrm{HI}$ diterima. Dengan demikian CAR, BOPO dan NPF berpengaruh positif dan signifikan terhadap ROA.

\section{Pembahasan}

Berdasarkan hasil pengujian hipotesis pertama dapat dilihat bahwa Capital to Adequecy Ratio (CAR) tidak berpengaruh signifikan terhadap Return on Assets (ROA). Artinya, besar kecilnya nilai CAR tidak dapat mempengaruhi besar kecilnya ROA Bank Umum Syariah.

Hasil penelitian ini sejalan dengan penelitian yang dilakukan oleh Syaugy (20I5) dan Petricia (2017) yang pada penelitianya menghasilkan bahwa Capital to Adequecy Ratio (CAR) tidak berpengaruh signifikan terhadap Return on Assets (ROA), sedangkan penelitian ini tidak sejalan dengan Ananda (2013), Abdillah (2015) dan Syamsurizal (2016) yang menyatakan bahwa bahwa Capital to Adequecy Ratio (CAR) berpengaruh signifikan terhadap Return on Assets (ROA).

Biaya Operasional/Pendapatan Operasional (BOPO) berpengaruh signifikan negatif terhadap Return on Assets (ROA), hal ini 
dikarenakan jika BOPO mengalami kenaikan maka ROA Bank Umum Syariah akan menurun dan sebaliknya.Hasil penelitian ini konsisten dengan Aditya (20/3), Ananda (20/3), Syamsurizal (2016) dan Petricia (2017), BOPO berpengaruh signifikan negatif terhadap ROA.

Non Performing Financing (NPF) berpengaruh signifikan negatif terhadap Return on Assets (ROA), hal ini menunjukkan bahwa semakin besar NPF menunjukan kualitas pembiayaan Bank Umum Syariah semakin buruk dan akan berdampak pada penurunan laba Bank Umum Syariah.Hasil penelitian ini konsisten dengan Ananda (20I3), NPF berpengaruh signifikan negatif terhadap ROA.

Berdasarkan hasil Uji Simultan (uji F), hasil penelitian ini menjelaskan bahwa variabel Capital to Adequecy Ratio (CAR), Biaya Operasional/Pendapatan Operasional (BOPO) dan Non Performing Financing (NPF) berpengaruh secara simultan terhadap variabel depeden (ROA).

\section{PENUTUP}

\section{Kesimpulan}

Capital to Adequecy Ratio (CAR) periode 20I2-20I7 Bank Umum Syariah, secara parsial tidak berpengaruh terhadap Return on Assets (ROA) pada Bank Umum Syariah. Semakin tinggi CAR tidak terbukti berpengaruh terhadap profitablilitas Bank Umum Syariah.

Operasional/Pendapatan Operasional (BOPO) secara parsial berpengaruh negatif dan signifikan terhadap Return on Assets (ROA) pada Bank Umum Syariah. Jika BOPO mengalami kenaikan maka profitabilitas Bank Umum Syariah menurun dan sebaliknya.

Non Performing Financing (NPF), secara parsial berpengaruh negatif dan signifikan terhadap Return on Assets (ROA) pada Bank Umum Syariah. Semakin besar NPF menunjukan kualitas pembiayaan Bank Umum Syariah semakin buruk dan berdampak pada penurunan laba Bank Umum Syariah.

Secara simultan variabel CAR,BOPO dan NPF pengaruh signifikan terhadap variabel depeden (ROA) Bank Umum Syariah.

\section{Saran}

Saran dari hasil penelitian ini adalah :

I. Diharapkan Bank Umum Syariah mampu menjaga cadangan modal dan diharapkan dapat memberikan alokasi yang besar pada sektor yang produktif yang dapat meningkatkan laba.
2. Harus menjaga tingkat efisiensi dan kemampuan bank dalam melakukan kegiatan operasinya. Semakin rendah tingkat BOPO menunjukkan semakin efisien bank tersebut.

3. Harus mampu menekan besarnya pembiayaan yang tidak lancar dan seharusnya bank perlu melakukan pengecekan terhadap calon nasabah dan melakukan pengawasan pembiayaan atau kredit.

4. Bagi penelitian selanjutnya diharapkan mampu menambah variabel independen yang lain yang dapat mempengaruhi ROA dan memperpanjang waktu penelitian sehingga akan diperoleh hasil yang lebih baik lagi

\section{DAFTAR PUSTAKA}

Abdillah Rahmad. 20I5.Analisis Faktorfaktor yang Mempengaruhi Profitabilitas Bank Syariah di Indonesia (periode 2008-20I5). Universitas Negeri Islam Syarif Hidayatullah Jakarta.

Almunawwaroh Medina dan Rina Marliana. 2018. Pengaruh CAR, NPF dan FDR Terhadap Profitabilitas Bank Syariah di Indonesia.Universitas Siliwangi.

Aditya Ahmad. 2013. Analisis Faktor-faktor yang Mempengaruhi Profitabilitas Bank Syariah di Indonesia. Universitas Negeri Islam Syarif Hidayatullah Jakarta.

Aditya Muhammad. 2013.Analisis Pengaruh CAR, FDR, NPF dan BOPO terhadap ROA Bank Umum Syariah. IAIN Sumatera Utara Medan.

Ghozali, Imam. 2016. Aplikasi Analisis Multivariate dengan Program IBM SPSS 2I. Semarang: Badan Penerbit Universitas Diponegoro

Halim Abdul \& Sarwoko. 2016. Manajemen Keuangan. Yogyakarta: BPFE

Kasmir. 2013.Bank dan Lembaga Keuangan Lainnya. Jakarta: Rajawali Pers

Kasmir. 2017. Analisis Laporan Keuangan. Jakarta: Rajawali Pers

Kasmir. 2016. Pengantar Manajemen Keuangan. Jakarta: Kencana

Lupi Muhammad. 2016. Pengaruh CAR (Capital Adequacy Ratio), NPF (Non Performing Financing, FDR (Financing To Deposit Ratio) dan Pembiayaan Bagi Hasil Terhadap ROA (Return On Asset) pada BUS (Bank Umum Syariah) Tahun 20 I I- 
2015. Universitas Muhammadiyah

Tangerang.

Sigiyono. 2016. Metode Penelitian

Kuantitatif, Kualitatif dan R\&D.

Bandung: Alfabeta

Syamsurizal. 2016. Pengaruh CAR (Capital

Adequacy Ratio), NPF (Non

Performing Financing) dan BOPO

(Biaya Operasional Pendapatan

Operasional) Terhadap ROA

(Return On Asset) pada BUS (Bank

Umum Syariah) Yang Terdaftardi

BI (Bank Indonesia). Universitas Islam

Negeri Sultan Syarif Kasim Riau. Jurnal

Penelitian sosial keagamaan, Vol.19, No.2.

Saugi Ahmad. 2015. Pengaruh CAR, FDR,

INFLASI dan BI RATE terhadap

ROA Bank Umum Syariah.

Universitas Negeri Islam Syarif Hidayatullah Jakarta.

Sumar'ih. 20I2.Konsep Kelembagaan Bank

Syariah. Yogyakarta: Graha IImu

www.ojk.go.id

www.wartaekonomi.co.id

www.bcasyariah.co.id

www.bnisyariah.co.id

www.brisyariah.co.id

www.syariahbukopin.co.id

www.syariahmandiri.co.id

www.bi.co.id

Yuni Petricia. 2017. Analisis Pengaruh CAR, NPF, FDR, BOPO, BI rate dan Inflasi terhadap Tingkat Profitabilitas Perbankan Syariah di Indonesia Periode 20II20 I7. Universitas Islam Indonesia 